\title{
Skin Regenerative and Anti-Cancer Actions of Copper Peptides
}

\author{
Loren Pickart* and Anna Margolina
}

Skin Biology, 4122 Factoria Boulevard SE, Suite Number 200, Bellevue, WA 98006, USA; anna@amargolina.com

* Correspondence: lorenpickart@skinbiology.com

Received: 26 March 2018; Accepted: 17 April 2018; Published: 21 April 2018

check for updates

\begin{abstract}
Topical remedies capable of protecting skin from damage and supporting its regeneration can improve skin's health as well as its appearance. Small copper peptides have an excellent safety record and are widely used in cosmetic products. The most studied copper peptide is GHK-Cu (glycyl-L-histidyl-L-lysine), a small copper-binding peptide, naturally present in human plasma. Since its discovery in 1973, in vivo and in vitro studies have shown that GHK-Cu possesses a wealth of health-positive actions including improving wound contraction and epithelization, and increasing the production of growth factors and activity of antioxidant enzymes. Recently, gene expression profiling shed new light on diverse biological actions of GHK-Cu. The present paper discusses evidence of GHK-Cu and other small copper peptides possessing potent anti-cancer properties.
\end{abstract}

Keywords: GHK-Cu; copper peptides; skin cancer; gene profiling; gene expression; regeneration

\section{Introduction}

Peptides are widely popular cosmetic ingredients. They achieve instant improvement of skin's appearance by moisturizing skin and conditioning its surface layer, and they are shown to possess various biological activity. Because of their small size, some of them are able to penetrate the stratum corneum. Copper peptides are small peptides under a molecular weight of $700 \mathrm{Da}$ that are chelated to copper $2+$. They may be synthesized by chemical means or produced by enzymatic digestion of proteins. Such peptides have an excellent safety profile and can heal wounds, improve the condition of skin, and increase hair growth in young mice [1]. Numerous studies confirmed the ability of copper peptides to improve condition of aging skin, which make them indispensable in anti-aging and protective cosmetic products [2,3].

The most studied regenerative copper peptide is GHK (glycyl-L-histidyl-L-lysine). It has a high affinity for copper ions and usually exists as a copper complex GHK-Cu. The most well-studied activities of GHK-Cu are its wound-healing and skin regenerative actions. It has been shown to greatly improve conditions of aging skin—reducing wrinkles and sagging skin, reducing pigmentation, and stimulating collagen, elastin, and glycosaminoglycans [4].

The author (Pickart) was first to isolate GHK from albumin fraction in human plasma in 1973. When plasma from young donors was added to liver cells from older donors, they started making proteins more characteristic to younger donors. An active component from plasma, which possessed the same properties, was identified as a glycyl-L-histidyl-L-lysine peptide [5,6].

GHK, which is naturally present in human blood, declines with age. Early research showed that GHK stimulates synthesis of collagen, elastin, and glycosaminoglycans in skin, accelerates wound healing, restores function of damaged fibroblasts, reduces scarring, and improves regeneration of skin, stomach, and intestinal linings. GHK stimulates hair growth and is used to improve outcomes in hair grafting [7]. 
GHK has a high affinity for the copper 2+ ion and can easily obtain copper $2+$ from its transport site on human plasma albumin. There are experiments that use copper-free GHK with successful results but all of our studies indicated copper 2+ is necessary for most GHK effects. The copper chelator bathocuproine abolishes GHK actions. If a test system has ample $\mathrm{Cu} 2+$ available, the GHK will easily obtain the necessary copper $2+[8]$.

It has been suggested by Peled et al. that copper-free GHK promotes the survival of stem cells and possibly the de-differentiation of cells, while GHK with copper 2+ promotes cell differentiation [9].

The understanding of GHK actions has been greatly aided by the use of gene expression data. In 2010, the Broad Institute of Boston measured the effects of GHK on 13,424 of the estimated 22,277 known human genes at that time. This provided us with expression of 4192 genes with plus or minus $50 \%$ changes from the 13,424 genes. This led to consecutive studies, which confirmed that GHK-Cu is able to up- and down-regulate a significant number of human genes, essentially resetting the human genome back to health (see Table 1).

Table 1. Percentage of Genes Affected by GHK.

\begin{tabular}{ccc}
\hline Percentage of Change & Genes Stimulated & Genes Suppressed \\
\hline $50-99 \%$ & 1569 & 583 \\
$100-199 \%$ & 646 & 469 \\
$200-299 \%$ & 227 & 196 \\
$300-599 \%$ & 196 & 207 \\
$600-899 \%$ & 39 & 47 \\
$900-1199 \%$ & 8 & 7 \\
$1200 \%$ or more & 2 & 4 \\
\hline
\end{tabular}

In 2012, GHK was found to reverse damage and stimulate regeneration in COPD (chronic obstructive lung disease) lung tissue by reversing gene expression associated with emphysema-related lung destruction [10].

According to the Broad Institute data, GHK stimulates or suppresses $31.2 \%$ of human genes with a change of $50 \%$ or more (stimulating $59 \%$ of the genes and suppressing $41 \%$ ) [11].

GHK-Cu modulates expression of numerous genes associated with regulation of important biochemical pathways important for skin repair and regeneration [12].

These gene studies shed new light on previous laboratory data, bringing better understanding of multiple protective and regenerative actions of $\mathrm{GHK}-\mathrm{Cu}$ which have puzzled scientists for over four decades.

In addition, a study that used fetal lung fibroblasts also found GHK to have extensive actions of gene expression relevant to tissue repair and induced dose-response gene expression on 329 genes associated with extracellular matrix composition [13].

The fact that GHK has gene-modulating effects is important, because as science has now demonstrated, age-related changes in gene expression are not permanent and can be reversed. Recent studies have demonstrated that physical exercise for $30 \mathrm{~min}$ a day, three times a week can revert gene expression in mitochondrial human DNA in older humans to a gene expression that is more like that of a younger person. Other studies showed positive effects of diet, moderate wine consumption, and meditation $[14,15]$.

The present paper discusses skin regenerative and anti-cancer actions of GHK-Cu in the light of new gene profiling studies.

\section{Regenerative and Anti-Cancer Actions of Copper Peptides}

The idea that certain tissue-regenerative molecules could also possess anti-cancer actions is new and unexpected. Previously, tissue regenerative proteins such as PDGF (platelet-derived growth factor) and TGF (Transforming Growth Factor) were promising candidates for the treatment of bedsores and 
diabetic ulcers. However, both compounds were later found to stimulate, and perhaps help induce, cancers [16-20].

We will present our research on the anti-cancer actions of copper peptides in a generally chronological order as the ideas developed.

In 1983, Linus Pauling and his group theorized that a copper-binding peptide (Gly-Gly-His) with copper $2+$ would oxidize ascorbic acid and kill cancer cells. This approach did work in cell culture. When used in mice, the system strongly inhibited the growth of Ehrlich ascites tumor cells. However, the copper peptide did not significantly oxidize the ascorbic acid in the mice. The Pauling group concluded that the anti-cancer activities were due to the copper peptide and not to an interaction with ascorbic acid [21].

In 2010, a study from the Singapore General hospital, using Connectivity Map (CMap) from the Broad Institute in Boston to obtain gene expression data, searched for molecular treatments for aggressive metastatic colon cancer. Two wound-healing compounds, GHK at 1 micromolar and securinine at 18 micromolar, were the computer-recommended treatment molecules chosen from 1309 bioactive compounds for the cancer treatment. The Broad data indicated that the two healing compounds were suppressing such node molecules associated with metastasis such as YWHAB, MAP3K5, LMNA, APP, GNAQ, F3, NFACTC2, and TGM2. Both GHK and securinine promote wound healing, extracellular remodeling, and macrophage activation [22].

In 2012, Matalka et al. provided additional links between GHK and cancer. Healthy mammalian cells have a system to terminate the cell if DNA is made incorrectly (programmed cell death or apoptosis). However, cancer cells evade this system by shutting it down. Matalka et al. reported that GHK or GHK-PEG (GHK-Polyethylene glycol) both reactivated apoptosis at 1 to 10 nanomolar and inhibited cell growth of human SH-SY5Y neuroblastoma cells and human U937 histiocytic lymphoma cells. In contrast, both GHK and GHK-PEG increased the replication of NIH3T3 fibroblast cells [23].

In 2014, using the Broad Institute CMap, Pickart et al. found gene expression changes induced by GHK. This included 84 cancer or growth inhibitory genes. Tables $2-4$ show GHK's effect on genes associated with apoptosis, cancer suppression, and cancer progression. The names of the proteins and their functions are obtained from the NCBI GENE database. Pickart et al. also tested Pauling's method but used GHK copper 2+ and ascorbic acid instead of the Gly-Gly-His in the treatment. Mouse sarcoma 180 was used, and the treatment produced a remarkable suppression of the tumor growth [24].

Table 2. GHK and Gene Expression of Programmed Cell Death (Apoptosis) Genes.

\begin{tabular}{ccc}
\hline Gene & Percent Change in Gene Expression & Comment \\
CASP 1 & 432 & $\begin{array}{c}\text { Caspase 1 induces apoptosis in human keratinocytes after } \\
\text { UV-radiation. Plays a protective role against UV-induced skin } \\
\text { cancer [25]. }\end{array}$ \\
\hline CASP 8 & 399 & $\begin{array}{c}\text { Caspase 8. A member of the caspase family, involved in } \\
\text { programmed cell death. }\end{array}$ \\
\hline CASP 10 & 195 & $\begin{array}{c}\text { Caspase 10. Cleaves and activates caspases 3 and 7. Processed by } \\
\text { caspase 8. }\end{array}$ \\
\hline NLRP1 & 249 & $\begin{array}{c}\text { A member of Ced-4 family of apoptosis proteins. A key mediator } \\
\text { of apoptosis and a member of inflammasomes protein family. } \\
\text { Mutations in this gene increase skin susceptibility to UV-induced } \\
\text { skin cancer [26]. }\end{array}$ \\
\hline CARD10 & 173 & \begin{tabular}{c} 
Caspase recruitment domain. \\
\hline
\end{tabular}
\end{tabular}


Table 3. GHK and Gene Expression in Cancer Suppressors.

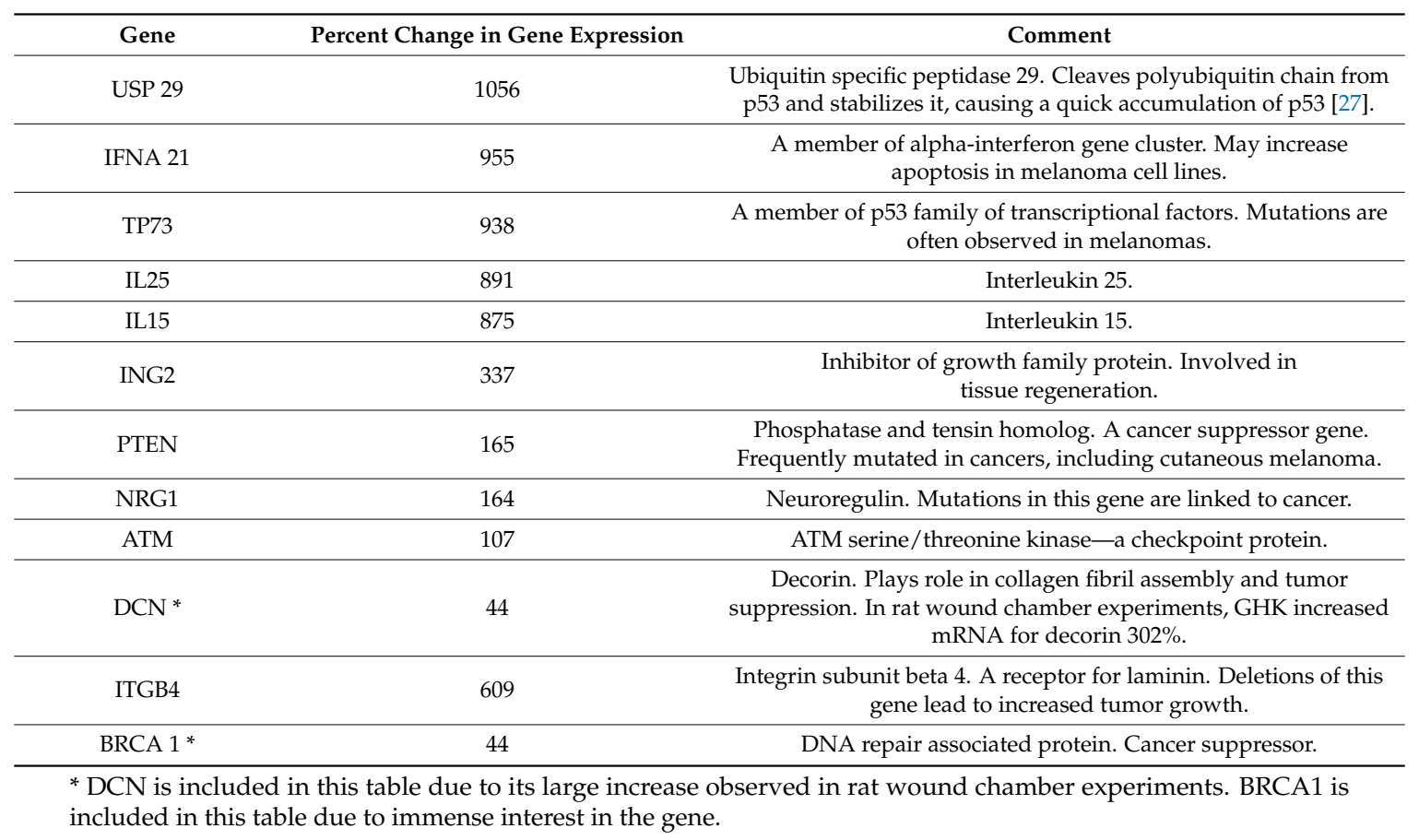

Table 4. GHK Downregulates Gene Expression in Some Cancer Enhancers.

\begin{tabular}{ccc}
\hline Gene & Percent Change in Gene Expression & Comment \\
\hline ABCB1 & -1537 & $\begin{array}{c}\text { ATP binding subfamily B member 1. Increases drug resistance in } \\
\text { cancer cells. }\end{array}$ \\
\hline STAT5 & -982 & $\begin{array}{c}\text { A member of the STAT family of transcriptional factors. Increases } \\
\text { resistance of melanoma cells to interferon treatment [28]. }\end{array}$ \\
\hline FGFR2 & -904 & $\begin{array}{c}\text { Fibroblasts growth factor receptor family. FGFR2 inhibitors reduce } \\
\text { growth of melanomas. }\end{array}$ \\
\hline FAIM2 & -749 & $\begin{array}{c}\text { Fas apoptotic inhibitory molecule 2. Prevents apoptosis. } \\
\text { Mutations in FAS system are common in many non-melanoma } \\
\text { skin cancers [29]. }\end{array}$ \\
\hline
\end{tabular}

\section{GHK May Support DNA Repair}

Since skin is exposed to a multitude of detrimental environmental factors, including UV-radiation, its cells are at risk of DNA damage. Mammalian cells have DNA repair mechanisms, which guard skin against cancer development [30]. Compounds that help repair DNA damage such as DNA repair enzymes have been proposed to help prevent skin cancer [31]. The downside of such approach is the relative large size of enzyme molecules, which, when used in in cosmetic formulations, would make it difficult to deliver to their targets.

Pollard et al. demonstrated GHK's ability to reverse detrimental changes in irradiated cultured human fibroblasts exposed to radioactive treatment (5000 rad). Irradiated control fibroblasts showed impaired profile of growth factor and collagen synthesis. However, when treated with GHK-Cu at $\left(1 \times 10^{-9} \mathrm{~mol} / \mathrm{L}\right)$, cells that received the same radiation treatment had a growth pattern and secretion of growth factors similar to the normal (non-irradiated) control cells. In addition, GHK-treated irradiated fibroblasts increased their secretion of essential growth factors such basic fibroblast growth factor and vascular endothelial growth factor [32].

In our work with the Broad Institute CMap, we found that GHK stimulates gene expression for DNA Repair genes (47 UP, 5 DOWN). This suggests a positive effect on DNA repair systems. Since one of the effects of radiation is DNA damage, stimulation of DNA repair genes may explain the observed positive effects on irradiated fibroblasts. We can hypothesize that some of the mechanisms behind 
beneficial effects on aging skin's condition, described above, can be also explained through increased DNA repair genes. See Table 5.

Table 5. Most Affected DNA Repair Genes.

\begin{tabular}{ccc}
\hline Gene & Percent Change in Gene Expression & Comments \\
\hline PARP3 & 253 & $\begin{array}{c}\text { Poly (ADP-ribose) polymerase family, member 3. DNA repair, } \\
\text { regulation of apoptosis, genomic stability. }\end{array}$ \\
\hline POLM & 225 & DNA polymerase mu. DNA repair enzyme. \\
\hline RAD50 & 175 & $\begin{array}{c}\text { Double strand break repair protein. DNA repair, cell cycle } \\
\text { checkpoint activation. }\end{array}$ \\
\hline RARA & 123 & retinoic acid receptor alpha. \\
\hline
\end{tabular}

\section{Anti-Inflammatory Actions of GHK-Cu}

Inflammation is now considered a key factor in tumor progression and chronic inflammation from incomplete wound healing has been shown to be causative in many cancers [33]. Wound-repair studies in animals as well as in vitro studies confirms strong anti-inflammatory effects of GHK-Cu. GHK was shown to reduce inflammatory response in bleomycin-induced lung injury in mice. GHK reduced inflammatory cells infiltration and TNF- $\alpha$ and IL- 6 expression in bronchoalveolar lavage fluid (BALF) and MPO in lung extracts [34]. In dermal fibroblasts, GHK and its copper complexes decreased IGF-2-dependent TGF- $\beta 1$ secretion as well as decreased TNF-alpha dependent secretion of IL-6, thus reducing inflammation $[35,36]$.

\section{Anti-Oxidant Actions of GHK-Cu}

Among factors that can accelerate skin aging and cause skin cancer are reactive oxygen species, and other types of free radicals, which can trigger oxidative processes and lead to DNA damage. Since skin is exposed to UV-radiation and other environmental factors that can trigger production of free radicals, it is essential that it has good antioxidant defense. Multiple studies established GHK-Cu's ability to protect cells from oxidative damage and improve antioxidant defense.

Parks et al. demonstrated GHK-Cu's effects on acute lung injury in vitro and in vivo. In lipopolysaccharide-induced macrophages and in vivo, GHK-Cu reduced Reactive Oxygen Species (ROS), increased superoxide dismutase (SOD) activity, and decreased TNF-1 and IL-6 production. The authors propose that GHK-Cu prevents activation of NFkB's p65 and p38 MAPK. P38 protein kinases have pro-inflammatory activity, and p65 activation plays an important role in cancer development [37].

GHK protects cultured skin keratinocytes from lethal ultraviolet radiation damage by quenching reactive carbonyl species such as 4-hydroxynonenal, acrolein, malondialdehyde, and glyoxal. The effect was observed with $20 \mathrm{mg} / \mathrm{mL}$ or $0.2 \%$ concentrations of GHK, which can be safely used in protective cosmetic formulations such as sunscreens [38-40].

GHK prevented oxidation of low-density lipoproteins induced by copper ions and was more effective than superoxide dismutase (SOD1), which blocked only $20 \%$ of oxidation [41]. Also, GHK-Cu produced an $87 \%$ inhibition of iron release from ferritin, presumably by blocking iron's exit channels from the protein. Free iron ions trigger lipid oxidation, so by blocking iron release from ferritin, GHK would prevent lipid oxidation [42].

GHK protected liver cells from damage caused by dichloromethane poisoning by blocking formation of dichloromethane free radicals. For five days before administering dichloromethane, rats were injected intraperitoneally with $1.5 \mathrm{mg} / \mathrm{kg}$ of GHK. Compared to the control, hepatocytes of GHK-injected rats retained their functional activity [43].

Also, intraperitoneal injections of a peptide mixture including GHK $(0.5 \mu \mathrm{g} / \mathrm{kg})$, dalargin $(1.2 \mu \mathrm{g} / \mathrm{kg})$, and thymogen $(0.5 \mu \mathrm{g} / \mathrm{kg})$ for 10 days in rats led to increased catalase activity and a decrease of malonic dialdehyde, which is a marker for lipid oxidation [44]. 
GHK-Cu was also found to elevate the level of antioxidant enzymes in the dermal wounds in rabbits and increase expression of antioxidant enzymes in diabetic wounds in rats, resulting in a higher level of antioxidants such as glutathione and ascorbic acid [45-47].

In addition, in Table 6 we summarized effects of GHK on antioxidant genes.

Table 6. GHK effect on genes related to antioxidant defense.

\begin{tabular}{|c|c|c|}
\hline GENES & Percent Change in Gene Expression & Comment \\
\hline TLE1 & 762 & $\begin{array}{l}\text { Transducin like enhancer of split } 1 \text {. Tumor suppressor. Reduces } \\
\text { inflammation and modulates NF-kb pathway. Considered to have } \\
\text { a potential in cancer therapy [48]. }\end{array}$ \\
\hline SPRR2C & 721 & $\begin{array}{l}\text { Proline-rich small protein. Its expression increases in } \\
\text { keratinocytes after UV-radiation. }\end{array}$ \\
\hline APOM & 403 & $\begin{array}{l}\text { Apolipoprotein. Binds oxidized phospholipids and increases the } \\
\text { antioxidant effect of HDL. }\end{array}$ \\
\hline PON3 & 319 & Paraoxonase 3 . Inhibits oxidation of HDL. \\
\hline IL18BP & 295 & $\begin{array}{l}\text { Interleukin } 18 \text { binding protein. An antagonist of a highly } \\
\text { inflammatory protein IL } 18 .\end{array}$ \\
\hline $\mathrm{HEPH}$ & 217 & $\begin{array}{l}\text { Hephaestin. Regulates iron and copper transport. Prevents } \\
\text { oxidative damage. }\end{array}$ \\
\hline GPSM3 & 193 & $\begin{array}{c}\text { G protein signaling modulator 3. Expressed in leukocytes and } \\
\text { lymph organs. }\end{array}$ \\
\hline FABP1 & 186 & $\begin{array}{l}\text { Fatty acids binding protein } 1 \text {. Plays role in fatty acids metabolism. } \\
\text { Reduces intracellular ROS level from oxidation of fatty acids. }\end{array}$ \\
\hline MT3 & 142 & $\begin{array}{c}\text { Metallothionein } 3 \text {. A member of metallothionein family. } \\
\text { Binds bivalent metal ions, such as copper } 2+\text {. Plays an important } \\
\text { role in copper homeostasis. }\end{array}$ \\
\hline PTGS2 & 120 & Prostaglandin-endoperoxide synthase 2 . Acts as a peroxidase. \\
\hline SLC2A9 & 117 & $\begin{array}{l}\text { Solute carrier family } 2 \text { member 9, involved in glucose homeostasis. } \\
\text { Upregulation reduces ROS accumulation [49]. }\end{array}$ \\
\hline IL17A & -1018 & Interleukin $17 \mathrm{~A}$, a proinflammatory cytokine. \\
\hline
\end{tabular}

\section{Anti-Cancer Copper-Peptides from Enzymatic Degradation of Proteins}

Over the years, we developed the use of copper peptides from digestion of soy proteins. Such types of peptides were used for years for intraparenteral intravenous feeding of patients and are considered very safe. Such peptides, when chelated to copper $2+$, improved both skin quality and healed wounds.

In 2012, we filed a patent on using these non-toxic and natural copper peptides as anti-cancer actives, which has since been issued. Now, as more and more experimental and gene profiling data support such use of copper peptides, the time has come for conducting actual clinical studies [50].

\section{Conclusions}

Small copper peptides, which have a long history of being used in skin care products and an excellent safety record, as well as possess well-documented wound healing, tissue repair and remodeling, anti-inflammatory, anti-antioxidant, and DNA repair properties, are now attracting attention as potent gene modulators, which can reverse expression of multiple genes involved in biochemical pathways associated with cancer growth and progression. Such peptides are inexpensive, can be easily incorporated in liposomes and other vehicles and applied as skin creams, serums, patches, etc. Copper-peptides can be also taken orally as a dietary supplement in liposomal form [51].

Conflicts of Interest: The authors declare no conflict of interest. 


\section{References}

1. Pickart, L. Tissue Protective and Regenerative Compositions. U.S. Patent 5,888,522, 30 March 1999.

2. Gorouhi, F.; Maibach, H.I. Role of topical peptides in preventing and treating aged skin. Int. J. Cosmet. Sci. 2009, 31, 327-345. [CrossRef] [PubMed]

3. Pickart, L.; Margolina, A. Anti-Aging Activity of the GHK Peptide-The skin and beyond. J. Aging. Res. Clin. Pract. 2012, 1, 13-16.

4. Finkley, M.B.; Appa, Y.; Bhandarkar, S. Copper Peptide and Skin. In Cosmeceuticals and Active Cosmetics: Drugs vs. Cosmetics; Elsner, P., Maibach, H.I., Eds.; Marcel Dekker: New York, NY, USA, 2005; pp. 549-563.

5. Pickart, L. The human tri-peptide GHK and tissue remodeling. J. Biomater. Sci. Polym. Ed. 2008, 19, 969-988. [CrossRef] [PubMed]

6. Pickart, L. A Tripeptide from Human Serum Which Enhances the Growth of Neoplastic Hepatocytes and the Survival of Normal Hepatocytes. Ph.D. Thesis, University of California, San Francisco, CA, USA, 1973.

7. Pickart, L.; Vasquez-Soltero, J.M.; Margolina, A. Resetting Skin Genome Back to Health Naturally with GHK. In Textbook of Aging Skin; Farage, M.A., Miller, K.W., Maibach, H.I., Eds.; Springer: Berlin, Germany, 2017. [CrossRef]

8. Pickart, L.; Vasquez-Soltero, J.; Margolina, A. The Effect of the Human Peptide GHK on Gene Expression Relevant to Nervous System Function and Cognitive Decline. Brain Sci. 2017, 7, 20. [CrossRef] [PubMed]

9. Pickart, L.; Freedman, J.H.; Loker, W.J.; Peisach, J.; Perkins, C.M.; Stenkamp, R.E.; Weinstein, B. Growth-modulating plasma tripeptide may function by facilitating copper uptake into cells. Nature 1980, 288, 715-717. [CrossRef] [PubMed]

10. Peled, T.; Fibach, E.; Treves, A. Methods of Controlling Proliferation and Differentiation of Stem and Progenitor Cells. U.S. Patent 6,962,698, 8 November 2005.

11. Campbell, J.D.; McDonough, J.E.; Zeskind, J.E.; Hackett, T.L.; Pechkovsky, D.V.; Brandsma, C.A.; Suzuki, M.; Gosselink, J.V.; Liu, G.; Alekseyev, Y.O.; et al. A gene expression signature of emphysema-related lung destruction and its reversal by the tripeptide GHK. Genome Med. 2012, 4, 67. [CrossRef] [PubMed]

12. Pickart, L.; Vasquez-Soltero, J.M.; Margolina, A. GHK and DNA: Resetting the human genome to health. Biomed. Res. Int. 2014, 2014, 151479. [CrossRef] [PubMed]

13. Pickart, L.; Vasquez-Soltero, J.M.; Margolina, A. GHK Peptide as a Natural Modulator of Multiple Cellular Pathways in Skin Regeneration. Biomed Res. Int. 2015, 2015. [CrossRef] [PubMed]

14. McMurry, R.; Perdomo, C.; Liu, G.; Zhang, S.; Stevenson, C.; Campbell, J.; Spira, A.; Lenburg, M. GHK-Cu Elicits in vitro, Dose-Dependent Transcriptional Alterations in Pathways Relevant to Extracellular Matrix Composition. Am. Thorac. Soc. 2017, A73, A2446.

15. Szarcvel Szic, K.; Declerck, K.; Vidaković, M.; Vanden Berghe, W. From inflammaging to healthy aging by dietary lifestyle choices: Is epigenetics the key to personalized nutrition? Clin. Epigenetics 2015, 7, 33. [CrossRef] [PubMed]

16. Kaliman, P.; Alvarez-López, M.J.; Cosín-Tomás, M.; Rosenkranz, M.A.; Lutz, A.; Davidson, R.J. Rapid changes in histone deaconesses and inflammatory gene expression in expert meditators. Psychoneuroendocrinology 2014, 40, 96-107. [CrossRef] [PubMed]

17. Devarajan, E.; Song, Y.H.; Krishnappa, S.; Alt, E. Epithelial-mesenchymal transition in breast cancer lines is mediated through PDGF-D released by tissue-resident stem cells. Int. J. Cancer 2012, 131, 1023-1031. [CrossRef] [PubMed]

18. Farooqi, A.A.; Siddik, Z.H. Platelet-derived growth factor (PDGF) signaling in cancer: Rapidly emerging signalling landscape. Cell Biochem. Funct. 2015, 33, 257-265. [CrossRef] [PubMed]

19. Fabregat, I.; Fernando, J.; Mainez, J.; Sancho, P. TGF-beta signaling in cancer treatment. Curr. Pharm. Des. 2014, 20, 2934-2947. [CrossRef] [PubMed]

20. Zarzynska, J.M. Two faces of TGF-beta1 in breast cancer. Mediat. Inflamm. 2014, 141747. [CrossRef] [PubMed]

21. Kimoto, E.; Tanaka, H.; Gyotoku, J.; Morishige, F.; Pauling, L. Enhancement of antitumor activity of ascorbate against Ehrlich ascites tumor cells by the copper: Glycylglycylhistidine complex. Cancer Res. 1983, 43, 824-828. [PubMed]

22. Hong, Y.; Downey, T.; Eu, K.W.; Koh, P.K.; Cheah, P.Y. A “metastasis-prone" signature for early-stage mismatch-repair proficient sporadic colorectal cancer patients and its implications for possible therapeutics. Clin. Exp. Metastasis 2010, 27, 83-90. [CrossRef] [PubMed] 
23. Matalka, L.E.; Ford, A.; Unlap, M.T. The Tripeptide, GHK, Induces Programmed Cell Death in SH-SY5Y Neuroblastoma Cells. J. Biotechnol. Biomater. 2012, 2, 144. [CrossRef]

24. Pickart, L.; Vasquez-Soltero, J.M.; Pickart, F.; Majnarich, J.D. GHK, the human skin remodeling peptide, induces anti-cancer expression of numerous caspase, growth regulatory, and DNA repair genes. J. Anal. Oncol. 2014, 3, 79-87. [CrossRef]

25. Sollberger, G.; Strittmatter, G.E.; Grossi, S.; Garstkiewicz, M.; Auf dem Keller, U.; French, L.E.; Beer, H.D. Caspase-1 activity is required for UVB-induced apoptosis of human keratinocytes. J. Invest. Dermatol. 2015, 135, 1395-1404. [CrossRef] [PubMed]

26. Awad, F.; Assrawi, E.; Louvrier, C.; Jumeau, C.; Giurgea, I.; Amselem, S.; Karabina, S.A. Photoaging and skin cancer: Is the inflammasome the missing link? Mech. Ageing Dev. 2018. [CrossRef] [PubMed]

27. Liu, J.; Chung, H.J.; Vogt, M.; Jin, Y.; Malide, D.; He, L.; Dundr, M.; Levens, D. JTV1 co-activates FBP to induce USP29 transcription and stabilize p53 in response to oxidative stress. EMBO J. 2011, 30, 846-858. [CrossRef] [PubMed]

28. Machiraju, D.; Moll, I.; Gebhardt, C.; Sucker, A.; Buder-Bakhaya, K.; Schadendorf, D.; Hassel, J.C. STAT5 expression correlates with recurrence and survival in melanoma patients treated with interferon- $\alpha$. Melanoma Res. 2018. [CrossRef] [PubMed]

29. Boldrini, L.; Loggini, B.; Gisfredi, S.; Zucconi, Y.; Baldinotti, F.; Fogli, A.; Simi, P.; Cervadoro, G.; Barachini, P.; Basolo, F.; et al. Mutations of Fas (APO-1/CD95) and p53 genes in nonmelanoma skin cancer. J. Cutan. Med. Surg. 2003, 7, 112-118. [CrossRef] [PubMed]

30. Park, J.M.; Kang, T.H. Transcriptional and Posttranslational Regulation of Nucleotide Excision Repair: The Guardian of the Genome against Ultraviolet Radiation. Int. J. Mol. Sci. 2016, 4, 17. [CrossRef] [PubMed]

31. Kabir, Y.; Seidel, R.; Mcknight, B.; Moy, R. DNA repair enzymes: An important role in skin cancer prevention and reversal of photodamage-A review of the literature. J. Drugs Dermatol. 2015, 14, 297-303. [PubMed]

32. Pollard, J.D.; Quan, S.; Kang, T.; Koch, R.J. Effects of copper tripeptide on the growth and expression of growth factors by normal and irradiated fibroblasts. Arch. Facial Plast. Surg. 2005, 7, 27-31. [CrossRef] [PubMed]

33. Coussens, L.M.; Werb, Z. Inflammation and cancer. Nature 2002, 420, 860-867. [CrossRef] [PubMed]

34. Zhou, X.M.; Wang, G.L.; Wang, X.B.; Liu, L.; Zhang, Q.; Yin, Y.; Wang, Q.Y.; Kang, J.; Hou, G. GHK Peptide Inhibits Bleomycin-Induced Pulmonary Fibrosis in Mice by Suppressing TGF $\beta 1 /$ Smad-Mediated Epithelial-to-Mesenchymal Transition. Front. Pharmacol. 2017, 8, 904. [CrossRef] [PubMed]

35. Gruchlik, A.; Chodurek, E.; Dzierzewicz, Z. Effect of GLY-HIS-LYS and its copper complex on TGF- $\beta$ secretion in normal human dermal fibroblasts. Acta Pol. Pharm. 2014, 71, 954-958. [PubMed]

36. Gruchlik, A.; Jurzak, M.; Chodurek, E.; Dzierzewicz, Z. Effect of Gly-Gly-His, Gly-His-Lys and their copper complexes on TNF-alpha-dependent IL-6 secretion in normal human dermal fibroblasts. Acta Pol. Pharm. 2012, 69, 1303-1306. [PubMed]

37. Park, J.R.; Lee, H.; Kim, S.I.; Yang, S.R. The tri-peptide GHK-Cu complex ameliorates lipopolysaccharide-induced acute lung injury in mice. Oncotarget 2016, 7, 58405-58417. [CrossRef] [PubMed]

38. Beretta, G.; Arlandini, E.; Artali, R.; Anton, J.M.; Maffei Facino, R. Acrolein sequestering ability of the endogenous tripeptide glycyl-histidyl-lysine (GHK): Characterization of conjugation products by ESI-MSn and theoretical calculations. J. Pharm. Biomed. Anal. 2008, 47, 596-602. [CrossRef] [PubMed]

39. Beretta, G.; Artali, R.; Regazzoni, L.; Panigati, M.; Facino, R.M. Glycyl-histidyl-lysine (GHK) is a quencher of alpha,beta-4-hydroxy-trans-2-nonenal: A comparison with carnosine. Insights into the mechanism of reaction by electrospray ionization mass spectrometry, $1 \mathrm{H}$ NMR, and computational techniques. Chem. Res. Toxicol. 2007, 20, 1309-1314. [CrossRef] [PubMed]

40. Cebrian, J.; Messeguer, A.; Facino, R.M.; Garcia Anton, J.M. New anti-RNS and -RCS products for cosmetic treatment. Int. J. Cosmet. Sci. 2005, 27, 271-278. [CrossRef] [PubMed]

41. Thomas, C.E. The influence of medium components on $\mathrm{Cu}(2+)$-dependent oxidation of low-density lipoproteins and its sensitivity to superoxide dismutase. Biochim. Biophys. Acta 1992, 1128, 50-57. [CrossRef]

42. Miller, D.M.; DeSilva, D.; Pickart, L.; Aust, S.D. Effects of glycyl-histidyl-lysyl chelated Cu(II) on ferritin dependent lipid peroxidation. Adv. Exp. Med. Biol. 1990, 264, 79-84. [PubMed] 
43. Smakhtin, M.; Konoplia, A.I.; Sever'ianova, L.A.; Shveinov, I.A. Pharmacological correction of immuno-metabolic disorders with the peptide Gly-His-Lys in hepatic damage induced by tetrachloromethane. Patol. Fiziol. Eksp. Ter. 2003, 2, 19-21.

44. Cherdakov, V.Y.; Smakhtin, M.Y.; Dubrovin, G.M.; Dudka, V.T.; Bobyntsev, I.I. Synergetic antioxidant and reparative action of thymogen, dalargin and peptide Gly-His-Lys in tubular bone fractures. Exp. Biol. Med. 2010, 4, 15-20.

45. Gul, N.Y.; Topal, A.; Cangul, I.T.; Yanik, K. The effects of topical tripeptide copper complex and helium-neon laser on wound healing in rabbits. Vet. Dermatol. 2008, 19, 7-14. [CrossRef] [PubMed]

46. Arul, V.; Gopinath, D.; Gomathi, K.; Jayakumar, R. Biotinylated GHK peptide incorporated collagenous matrix: A novel biomaterial for dermal wound healing in rats. J. Biomed. Mater. Res. B Appl. Biomater. 2005, 73, 383-391. [CrossRef] [PubMed]

47. Arul, V.; Kartha, R.; Jayakumar, R.A. therapeutic approach for diabetic wound healing using biotinylated GHK incorporated collagen matrices. Life Sci. 2007, 80, 275-284. [CrossRef] [PubMed]

48. Ramasamy, S.; Saez, B.; Mukhopadhyay, S.; Ding, D.; Ahmed, A.M.; Chen, X.; Pucci, F.; Yamin, R.; Wang, J.; Pittet, M.J.; et al. Tle1 tumor suppressor negatively regulates inflammation in vivo and modulates NF- $\mathrm{B}$ inflammatory pathway. Proc. Natl. Acad. Sci. USA 2016, 113, 1871-1876. [CrossRef] [PubMed]

49. Han, X.; Yang, J.; Li, D.; Guo, Z. Overexpression of uric acid transporter SLC2A9 inhibits proliferation of hepatocellular carcinoma cells. Oncol. Res. 2018. [CrossRef] [PubMed]

50. Pickart, L.R.; Pickart, F.D. Non-Toxic Skin Cancer Therapy with Copper Peptides. U.S. Patent 9,586,989, 7 March 2017.

51. Li, P.; Nielsen, H.M.; Mullertz, A. Oral delivery of peptides and proteins using lipid-based drug delivery systems. Expert Opin. Drug Deliv. 2012, 9, 1289-1304. [CrossRef] [PubMed]

(C) 2018 by the authors. Licensee MDPI, Basel, Switzerland. This article is an open access article distributed under the terms and conditions of the Creative Commons Attribution (CC BY) license (http:/ / creativecommons.org/licenses/by/4.0/). 